Vol. 7 No. 2 Juli 2018

E-ISSN : 2502-3101 P-ISSN : 2302-528x

http://ojs.unud.ac.id/index.php/jmhu

\title{
Gugatan Pihak Ketiga Terhadap Eksekusi Barang Sitaan dalam Perkara Tindak Pidana Korupsi
}

\section{Teddy Widodo ${ }^{1}$}

1Kejaksaan Negeri Klungkung Bali, E-mail: tedhywidodo@gmail.com

\begin{tabular}{l} 
Info Artikel \\
\hline Masuk: 14 Maret 2018 \\
Diterima: 11 Juli 2018 \\
Terbit: 31 Juli 2018 \\
Keyword: \\
Third Party Lawsuit; \\
Execution of Confiscated \\
Goods; Corruption \\
\\
Corresponding Author: \\
Teddy Widodo, E-mail: \\
tedhywidodo@gmail.com \\
DOI: \\
10.24843/JMHU.2018.v07.i02 \\
Kata kunci: \\
Gugatan Pihak Ketiga; \\
Kksekusi Barang Sitaan; \\
\end{tabular}

\begin{abstract}
The criminal act of corruption is a financial and humanitarian crime that harms the state and reduces the people's right to better access to welfare. The settlement of corruption cases often involves many parties, including good third parties related to the evidence seized by the Prosecutor. Judgments in judicial practice still cause new problems. The Panel of Judges imposed a crime in the form of appropriation of property in the control of a wellintentioned third party. The purpose of this paper is to examine the legal status of a third party who has good faith in the execution of confiscated goods in the case of corruption and the role of the prosecutor in a third-party lawsuit related to the execution of confiscated goods in the case of corruption. The research method used is normative legal research with statutes approach and case approach. The study indicates that the legal measures that can be done by a good third party against the confiscated objects in the case of corruption must be in accordance with Article 19 of the Anti-Corruption Eradication Act. The role of the public prosecutor in a civil case is not a public prosecutor or executor but in a lawsuit as a State Attorney under Article 30 Paragraph (2) of Law Number 16 Year 2004 regarding the Attorney General of the Republic of Indonesia.
\end{abstract}

\section{Abstrak}

Tindak pidana korupsi adalah kejahatan keuangan dan kemanusiaan yang merugikan negara dan mengurangi hak rakyat untuk mendapat akses kesejahteraan yang lebih baik. Penyelesaian perkara tindak pidana korupsi seringkali melibatkan banyak pihak, termasuk pihak ketiga yang beritikad baik terkait dengan barang bukti yang disita oleh Penuntut Umum. Putusan-putusan dalam praktek peradilan masih menimbulkan masalah baru. Majelis Hakim menjatuhkan pidana berupa perampasan harta dalam penguasaan pihak ketiga yang beritikad baik. Tujuan penulisan ini untuk mengkaji kedudukan hukum pihak ketiga yang beritikad baik dalam eksekusi barang sitaan dalam perkara tindak pidana korupsi dan peranan jaksa dalam gugatan pihak ketiga terkait eksekusi barang sitaan dalam perkara tindak pidana korupsi. Metode penelitian yang digunakan adalah penelitian hukum normatif dengan pendekatan perundang-undangan dan pendekatan kasus. Hasil studi menunjukkan bahwa Upaya Hukum yang dapat dilakukan oleh pihak ketiga yang 
beritikad baik terhadap benda sitaan dalam perkara tindak pidana korupsi harus sesuai dengan Pasal 19 Undangundang Pemberantasan Tindak Pidana Korupsi. Peran jaksa dalam perkara perdata bukan sebagai penuntut umum atau eksekutor akan tetapi dalam perkara gugatan sebagai Jaksa Pengacara Negara berdasarkan Pasal 30 Ayat (2) Undang-undang Nomor 16 Tahun 2004 tentang Kejaksaan Republik Indonesia.

\section{Pendahuluan}

Korupsi di Indonesia berkembang secara sistemik, saking seringnya terjadi kasus korupsi, sehingga dianggap suatu kebiasaan dan bukan pelanggaran hukum. Korupsi merupakan ancaman yang nyata bagi suatu bangsa karena menyebabkan kerugian keuangan dan perekonomian negara sehingga menyebabkan terhambatnya pembangunan nasional. Modus operandi dari kejahatan korupsi berkembang dan sangat beragam, sehingga memerlukan upaya-upaya penegakan yang juga semakin tegas. Harapan penegakan hukum yang ideal dalam pemberantasan tindak pidana korupsi juga belum dapat tercapai secara maksimal, masih ditemukan beberapa putusan dalam praktek peradilan yang masih menimbulkan masalah baru, seperti Putusan MA No. 1153K/Pid/2005 tanggal 29 Agustus 2007 Jo Putusan PT Surabaya No. 02/Pid/2004/PT.SBY tanggal 10 September 2004 Jo Putusan PN Bondowoso No. 154/Pid.B/2002/PN.Bdw tanggal 20/10/ 2003, dengan amar putusannya menyatakan bahwa tanah pekarangan yang di atasnya berdiri sebuah bangunan rumah/kantor milik H. Sunaryo yang terletak dijalan Saliwiryo Pranowo Nomor 07 A Bondowoso, dirampas untuk negara dan segera dikosongkan. Berdasarkan putusan tersebut terlihat bahwa pertanggungjawaban pidana yang menjadi dasar penjatuhan pidana terhadap terdakwa secara individual. Dalam hal mana pidana dijatuhkan Majelis Hakim perkara ini menjatuhkan pidana berupa perampasan yang ada dalam penguasaan pihak ketiga yang beritikad baik yaitu Tri Subuh Fajarwati yang mana adalah istri dari H. Sunaryo.

Perkawinan orang tua Tri Subuh Fajarwati pada tahun 1990 telah memberikan uang kepada H. Sunaryo untuk membeli sebidang tanah pekarangan milik Hamidin sekeluarga dengan harga sebesar Rp. 2.300.000,00 (dua juta tiga ratus ribu rupiah) yang mana jual beli dilakukan di hadapan Drs. Darmanto Pribadi selaku PPAT Kepala Wilayah Kecamatan Bondowoso dengan Akta Jual Beli Nomor 25/Bond/Ktln/1990 dan kemudian langsung dibangun sebuah bangunan rumah sebagai tempat tinggal bersama antara Pelawan dengan H. Sunaryo. Tanah yang dirampas untuk negara sebagaimana tersebut dalam putusan atas H. Sunaryo, menurut Tri Subuh Fajarwati bukan merupakan hasil dari tindak pidana korupsi karena merupakan tanah pemberian dari orang tuanya dan atas putusan tersebut Tri Subuh Fajarwati merasa dirugikan sehingga mengajukan gugatan perdata Ke Pengadilan Negeri Bondowoso dan telah diputus dalam putusan nomor 02/Pdt.Plw/2014/PN.Bdw tanggal 10 Juni 2014 yang dalam amar putusannya menyatakan perlawanan dari pelawan tidak dapat diterima, kemudian putusan tersebut juga dikuatkan oleh putusan Pengadilan Tinggi dengan putusan nomor 436/PDT/2014/PT.SBY tanggal 3 Februari 2015. Sesudah putusan Pengadilan Tinggi tersebut diterima oleh pelawan, melalui kuasa hukumnya pelawan mengajukan kasasi, dan telah diputus dengan putusan nomor 
1948K/Pdt/2016 tanggal 26 November 2015 yang dalam amarnya menolak permohonan kasasi dari Pemohon.

Berdasarkan Pasal 19 ayat (1) Undang-undang Nomor 31 Tahun 1999 tentang pemberantasan Tindak Pidana Korupsi (yang selanjutnya disebut UU No. 31/1999) apabila merugikan hak-hak pihak ketiga yang beritikad baik, maka putusan pengadilan mengenai barang-barang yang bukan kepunyaan terdakwa tidak dijatuhkan. Apabila putusan perampasan barang pihak ketiga yang beritikad baik dijatuhkan maka pihak ketiga tersebut dapat mengajukan surat keberatan kepada pengadilan yang bersangkutan.

Pihak ketiga yang beritikad baik mendapat perlindungan hukum berkaitan dengan barang bukti yang dinyatakan dirampas untuk negara dalam perkara korupsi sebagaimana ditegaskan dalam Pasal 19 Undang-undang nomor 20 tahun 2001 tentang perubahan atas Undang-undang Nomor 31 Tahun 1999 tentang Pemberantasan Tindak Pidana Korupsi. Pada intinya ketentuan tersebut mengatur bahwa perampasan barang-barang bukan kepunyaan terdakwa tidak dijatuhkan, apabila hak-hak pihak ketiga yang beritikad baik akan dirugikan, pihak ketiga yang beritikad baik dapat mengajukan keberatan kepada pengadilan. Lebih lanjut juga ditentukan bahwa selama proses pengajuan surat keberatan tidak menangguhkan atau menghentikan pelaksanaan putusan pengadilan.

Berkaitan dengan perampasan terhadap barang/aset yang telah dialihkan atau dikuasai oleh pihak ketiga, maka pihak ketiga yang bersangkutan berhak atas konpensasi kerugian dari pelaku tindak pidana, jika memang terbukti apabila pihak ketiga merupakan pihak yang bersih dan kapabilitasnya tidak terkait dengan perbuatan pelaku tindak pidana (pihak ketiga yang beritikad baik) maksudnya dalam hal ini pihak ketiga mengetahui apakah aset tersebut berasal dari hasil kegiatan tindak pidana ataupun sarana tindak pidana, meskipun pihak ketiga telah melakukan pemeriksaan terhadap aset yang akan dikuasai tetapi kebenarannya ditutupi atau di rekayasa oleh pihak pelaku tindak pidana. ${ }^{1}$

Dalam studi ini, dengan mengacu pada latar belakang yang telah diuraikan sebelumnya, maka dikaji suatu permasalahan: Bagaimanakah kedudukan hukum pihak ketiga dalam eksekusi barang sitaan dalam perkara tindak pidana korupsi? Bagaimana peranan jaksa dalam gugatan pihak ketiga terhadap eksekusi barang sitaan dalam perkara tindak pidana korupsi?

Tujuan dari studi ini adalah untuk memberikan gambaran yang jelas tentang kedudukan pihak ketiga yang beritikad baik berkaitan dengan eksekusi barang sitaan dalam perkara tindak pidana korupsi serta mengelaborasi secara lebih mendalam peranan jaksa dalam gugatan pihak ketiga terhadap eksekusi barang sitaan dalam perkara tindak pidana korupsi.

Studi sebelumnya yang relevan dengan tulisan ini namun dengan fokus berbeda diantaranya pernah dilakukan oleh Ervien Rizky Aditya tahun 2017 yang berjudul

\footnotetext{
1 Yusuf, Y., Nurholish, R. (2010) Perlindungan Hukum Pihak Ketiga Yang Beritikad Baik Atas Barang Bukti Yang Dirampas Untuk Negara Dalam Perkara Tindak Pidana Korupsi. Fakultas Hukum Universitas Padjadjaran. Bandung. h. 105.
} 
Penerapan Kebijakan Diskresi Dalam Kaitannya Dengan Tindak Pidana Korupsi yang menggambarkan kekuasaan pemerintah sebagai pembuat kebijakan diskresi selalu berhadapan dengan adanya suatu permasalahan yang dihubungkan dengan tindak pidana korupsi. ${ }^{2}$ Lebih lanjut, Ni Wayan Sinaryati tahun 2015 mengkaji fungsi Jaksa dalam menuntut terdakwa berkaitan dengan pengembalian kerugian keuangan negara yang dapat dilakukan Jaksa Penuntut Umum selaku penegak hukum dan badan eksekutor melalui: membuat dakwaan yang cermat, jelas dan lengkap, membuat tuntutan yang tegas dan optimal, melakukan upaya hukum banding dan / atau kasasi terhadap putusan hakim yang tidak memuaskan, Jaksa Agung dapat mengajukan upaya hukum kasasi demi kepentingan hukum, mengingat secara perdata oleh Jaksa selaku pengacara Negara. ${ }^{3}$ Studi tentang penerapan ancaman sanksi pidana tambahan guna pengembalian kerugian keuangan negara berkaitan dengan tindak pidana korupsi, studi kasus di Pengadilan Negeri Denpasar dilakukan oleh Kadek Krisna Sintia Dewi tahun 2014. Hasil studinya menggambarkan dalam tataran implementasi ancaman sanksi pidana tambahan guna pengembalian kerugian keuangan negara dalam tindak pidana korupsi di Pengadilan Negeri Denpasar sudah diterapkan namun belum optimal. Hal ini dikarenakan masih adanya tuntutan Jaksa yang tidak mencantumkan pidana tambahan sehingga mempengaruhi pertimbangan Hakim dalam menjatuhkan Putusan. Akibatnya, upaya pengembalian kerugian keuangan negara karena tindak pidana korupsi menjadi tidak maksimal. ${ }^{4}$ Studi-studi yang telah dikemukakan sebelumnya meskipun juga berkaitan dengan tindak pidana korupsi, namun analisanya tidak berfokus pada Gugatan Pihak Ketiga terhadap eksekusi barang sitaan dalam perkara tindak pidana korupsi, sebagaimana difokuskan dalam studi ini.

Berkaitan dengan eksekusi harta benda yang diperoleh dari tindak pidana korupsi, maka harus dilakukan penafsiran terhadap ketentuan Pasal 18 Ayat (1) huruf b, yaitu tidak hanya ditafsirkan sebagai harta benda yang diperoleh dari hasil tindak pidana korupsi yang masih dikuasai oleh terpidana pada waktu putusan pengadilan, namun juga ditafsirkan termasuk harta benda yang diperoleh dari hasil tindak pidana korupsi, yang sudah dialihkan penguasaannya kepada orang lain. ${ }^{5}$ Dalam konteks ini tentunya juga harus ditafsirkan bahwa orang lain tersebut mengetahui bahwa harta benda yang dialihkan kepadanya sumbernya tidak halal yaitu dari kejahatan korupsi. Pengalihan harta benda kepada pihak lain, dalam realitanya bisa saja dialihkan kepada perusahaan atau korporasi. Sehubungan dengan hal tersebut, sebagaimana ditentukan dalam undang-undang maupun dalam realitanya bahwa tindak pidana korupsi sangat merugikan keuangan negara atau perekonomian negara serta menghambat pertumbuhan dan kelangsungan pembangunan nasional, namun melalui perubahan

2 Aditya, E. R. (2017). Penerapan Kebijakan Diskresi Dalam Kaitannya Dengan Tindak Pidana Korupsi. Jurnal Magister Hukum Udayana (Udayana Master Law Journal). 6(3). h. 404-416

3 Sinaryati, N. W. (2015). Fungsi Jaksa dalam Menuntut Terdakwa Korupsi untuk Pengembalian Kerugian Keuangan Negara Perspektif Sistem Peradilan Pidana Indonesia. Jurnal Magister Hukum Udayana (Udayana Master Law Journal). 4(1). h. 162-178.

${ }^{4}$ Dewi, K. K. S. (2014). Efektifitas Penerapan Ancaman Sanksi Pidana Tambahan Guna Pengembalian Kerugian Keuangan Negara dalam Tindak Pidana Korupsi (Studi Kasus di Pengadilan Negeri Denpasar). Jurnal Magister Hukum Udayana (Udayana Master Law Journal). 3(3). h. 368.

5 Sinulingga, E. E. (2017). Pengembalian Aset Hasil Tindak Pidana Korupsi Melalui Mekanisme Gugatan Perdata. Lex Administratum. 5(4). h. 123 
ketentuan tindak pidana korupsi yaitu melalui Undang-Undang No. 20 Tahun 2001 telah diatur beban pembuktian terbalik sebagaimana diatur dalam Pasal 37, terdakwa mempunyai hak untuk membuktikan dirinya tidak melakukan tindak pidana korupsi. Dalam hal si terdakwa dapat membuktikan tidak melakukan tindak pidana korupsi, maka pengadilan akan menggunakan pembuktian tersebut sebagai dasar untuk menyatakan dakwaan tidak terbukti. ${ }^{6}$

\section{Metode Penelitian}

Studi tentang perlindungan pihak ketiga yang beritikad baik yang sehubungan dengan tindak pidana korupsi relevan dikaji melalui jenis penelitian hukum normatif., dengan pendekatan undang-undang (statute approach), dilakukan dengan menelaah undangundang dan regulasi terkait kasus asset yang dialihkan, pendekatan kasus (case approach), dilakukan dengan cara melakukan telaah terhadap kasus-kasus yang berkaitan dengan isu yang dihadapi yang telah menjadi putusan pengadilan yang telah mempunyai kekuatan hukum tetap.

\section{Hasil dan Pembahasan}

\subsection{Kedudukan Hukum Pihak Ketiga Terhadap Eksekusi Barang Sitaan Dalam Perkara Tindak Pidana Korupsi}

Berdasarkan Pasal 193 KUHP diatur mengenai putusan pemidanaan. Dalam ketentuan ini dapat dipahami konsep pemidanaan berarti terdakwa dijatuhi hukuman pidana sesuai dengan ancaman yang ditentukan dalam pasal tindak pidana yang didakwakan. ${ }^{7}$ Penjatuhan pidana yang didakwakan kepada terdakwa didasarkan pada penilaian pengadilan sebagaimana dapat dicermati dari Pasal 193 ayat (1) KUHAP. Dalam hal terdakwa terbukti bersalah menurut pengadilan yaitu terbukti bersalah melakukan perbuatan yang didakwakan kepadanya, pengadilan menjatuhkan hukuman pidana terhadap terdakwa. Setiap putusan pengadilan baik pemidanaan maupun pelepasan dari segala tuntutan hukum, harus ditegaskan penentuan status barang bukti. Berpedoman pada Pasal 194 KUHAP, yang mengatur:

(1) Dalam hal putusan pemidanaan atau bebas atau lepas dari segala tuntutan hukum, pengadilan menetapkan supaya barang bukti yang disita diserahkan kepada pihak yang paling berhak menerima kembali yang namanya tercantum dalam putusan tersebut terkecuali jika menurut ketentuan undang-undang barang bukti itu harus dirampas untuk kepentingan negara atau dimusnahkan atau dirusak sehingga tidak dapat dipergunakan lagi.

(2) Kecuali apabila terdapat alasan yang sah, pengadilan menetapkan supaya barang bukti diserahkan segera sesudah sidang selesai.

(3) Perintah penyerahan barang bukti dilakukan tanpa disertai sesuatu apa pun kecuali dalam putusan pengadilan belum mempunyai kekuatan hukum tetap.

Dengan mencermati ketentuan Pasal 194 KUHAP dikaitkan dengan ketentuan Pasal 19 UU No. 31/1999 sebagaimana telah dirubah melalui UU No. 20 tahun 2001 terkait status barang bukti dapat dikemukakan bahwa benda yang disita sebagai barang bukti setelah perkara diputus dikembalikan pada pihak yang berhak sebagaimana dimaksud

6 Prasetyo, R. T., Ma'ruf, U., \& Mashdurohatun, A. (2017). Tindak Pidana Korporasi Dalam Perspektif Kebijakan Formulasi Hukum Pidana. Jurnal Hukum Khaira Ummah. 12(4). h. 735

7 Harahap, M. Y. (2016). Pembahasan dan Penerapan KUHAP: Pemeriksaan Sidang Pengadilan, Banding, Kasasi, dan Peninjauan Kembali. Cetakan Kelima Belas. Sinar Grafika. Jakarta. h. 354. 
dalam putusan hakim. dan benda barang bukti dirampas untuk kepentingan negara atau dimusnahkan. Selain itu, barang bukti dirampas untuk kepentingan negara atau dimusnahkan.

Berkaitan dengan pengembalian barang bukti kepada pihak yang berhak, siapa yang dianggap sebagai pihak yang berhak, kepada siapa barang bukti tersebut dikembalikan diserahkan kepada hakim yang bersangkutan setelah mendengar keterangan saksi dan terdakwa, baik mengenai perkaranya maupun menyangkut barang bukti dalam pemeriksaan sidang di pengadilan. ${ }^{8}$ Orang yang berhak menerima barang bukti, antara lain:

- Orang atau mereka dari siapa barang tersebut disita, yaitu orang atau mereka yang memegang atau menguasai barang itu pada waktu penyidik melakukan penyitaan dan ketika barang tersebut dalam pemeriksaan persidangan memang dialah yang berhak atas barang tersebut.

- Pemilik yang sebenarnya, sewaktu disita benda yang dijadikan barang bukti tidak dalam kekuasaan orang tersebut. Namun, dalam pemeriksaan ternyata benda tersebut adalah miliknya yang dalam perkara itu bertindak sebagai saksi korban. Hal ini sering terjadi dalam perkara kejahatan terhadap harta benda.

- Ahli waris, dalam hal yang berhak atas barang bukti tersebut telah meninggal dunia sebelum putusan dijatuhkan, maka berkenaan dengan barang bukti tersebut putusan hakim menetapkan bahwa barang bukti tersebut dikembalikan kepada ahli waris atau keluarganya.

- Pemegang hak terakhir, barang bukti dapat pula dikembalikan kepada pemegang hak terakhir atas benda tersebut asalkan dapat dibuktikan bahwa ia secara sah benar-benar mempunyai hak atas benda tersebut.

Penjatuhan putusan tindak pidana korupsi terhadap barang bukti yang bukan kepunyaan terdakwa tidak dapat dijatuhkan jika mengakibatkan hak pihak ketiga yang beritikad baik dirugikan. Ketentuan Pasal 19 ayat (1) UU No. 31/1999 tidak memberikan definisi tentang pihak ketiga yang beritikad baik. Meskipun dalam Pasal 80 KUHAP mengintrodusir istilah pihak ketiga, namun tidak memberikan definisi yang tegas mengenai pengertian atau definisi dari pihak ketiga sehingga akan menimbulkan penafsiran secara bebas tentang pengertian pihak ketiga yang beritikad baik.

Berdasarkan putusan pengadilan, barang bukti dalam perkara korupsi juga dapat dirampas untuk kepentingan negara atau dimusnahkan atau dirusak sebagaimana diatur dalam Pasal 194 ayat (1) KUHAP. Lebih lanjut berdasarkan Pasal 10 huruf b angka 2, dalam Pasal 39 KUHAP dapat dicermati bahwa perampasan terhadap barang tertentu merupakan salah satu dari hukuman tambahan.

Berdasarkan ketentuan diatas terkait dengan putusan tentang perampasan barang bukti untuk kepentingan negara apabila dihubungkan dengan Pasal 19 UU No.31/1999 Jo U.U. No 20 Tahun 2001 apabila putusan pengadilan menetapkan barang bukti disita untuk negara, hakim telah memandang bahwa penuntut umum telah membuktikan dakwaannya yang mana barang bukti yang disita diperoleh dari hasil

8 Afiah, R. N. (1988). Barang Bukti Dalam Proses Pidana, Sinar Grafika. Jakarta. h. 199. 
tindak pidana korupsi dengan didukung oleh alat bukti yang sah menurut hukum serta memiliki nilai pembuktian yang kuat.

Perkara tindak pidana korupsi yang dalam hal ini Tri Subuh Fajarwati merupakan istri dari terdakwa $\mathrm{H}$. Sunaryo, terkait dengan benda sitaan yang dijadikan barang bukti pada perkara $H$. Sunaryo, istri terdakwa merasa memiliki hak atas benda sitaan tersebut dan beranggapan bahwa benda yang disita tidak ada kaitannya dengan perkara tindak pidana korupsi yang menjerat H. Sunaryo. Pada putusan Mahkamah Agung Republik Indonesia Nomor 1153K/Pid/2005 tanggal 29 Agustus 2007 Jo Putusan Pengadilan Tinggi Surabaya Nomor 02/Pid/2004/PT.SBY tanggal 10 September 2004 Jo Putusan Pengadilan Negeri Bondowoso Nomor 154/Pid.B/2002/PN.Bdw tanggal 20 Oktober 2003, dengan amar putusannya menyatakan bahwa tanah pekarangan yang di atasnya berdiri sebuah bangunan rumah/kantor milik H. Sunaryo yang terletak dijalan Saliwiryo Pranowo Nomor 07 A Bondowoso, dirampas untuk negara dan segera dikosongkan.

Kedudukan hukum istri terdakwa dalam perkara tindak pidana korupsi yang menjerat H. Sunaryo merupakan pihak ketiga yang merasa dirugikan dengan adanya putusan tersebut. Dalam konteks ini apabila istri terdakwa memiliki legal standing untuk melakukan perlawanan pihak ketiga perlu memperhatikan ketentuan pasal 19 Undang-undang Nomor 31 Tahun 1999 sebagaimana telah dirubah dengan UU. No. 20 Tahun 2001.

Berdasarkan ketentuan-ketentuan hukum yang berlaku mengenai eksekusi barang sitaan dalam perkara tindak pidana korupsi, maka penulis beranggapan bahwa seharusnya Pelawan mengajukan keberatan dalam tenggang waktu yang ditentukan diatas dan bukan melalui proses perlawanan, apabila dihubungkan dengan Putusan Mahkamah Agung Nomor 1153K/Pid/2005 tertanggal 29 Agustus maka tenggang waktu untuk mengajukan keberatan dari istri $\mathrm{H}$. Sunaryo telah melewati batas waktu yang telah ditentukan.

\subsection{Peran Jaksa Dalam Gugatan Pihak Ketiga Terhadap Eksekusi Barang Sitaan Dalam Perkara Tindak Pidana Korupsi}

Berkaitan dengan peran jaksa dalam kasus Tindak Pidana Korupsi dan kaitannya dengan uraian kasus posisi yang sudah dikaji sebelumnya, dapat dikemukakan peran jaksa dapat dibedakan mengenai peran jaksa dalam hal jaksa yang menangani perkara tindak pidana korupsi dan jaksa yang menangani gugatan dari penggugat. Dalam hal perkara tindak pidana korupsi, jaksa yang menangani perkara H. Sunaryo merupakan jaksa yang diperintahkan untuk melakukan penuntutan sebagai penuntut umum berdasarkan Surat Perintah Penunjukan Jaksa Penuntut Umum Untuk Menyelesaikan Perkara Tindak Pidana (P-16A) ${ }^{9}$ dan pada saat putusan perkara tindak pidana korupsi telah berkekuatan hukum tetap maka jaksa tersebut akan bertindak sebagai eksekutor

9 Lihat Keputusan Jaksa Agung Republik Indonesia Nomor: KEP-518/A/J.A/11/2011 Tentang Perubahan Keputusan Jaksa Agung Republik Indonesia Nomor: KEP132/JA/11/1994 tentang Administrasi Perkara Tindak Pidana. 
putusan untuk mengeksekusi terdakwa dan barang bukti terkait tindak pidana korupsi. ${ }^{10}$

Ketika gugatan oleh pihak ketiga diajukan ke Pengadilan Negeri yang mana perkara tersebut merupakan perkara bidang perdata, peran jaksa di sini bukanlah seorang penuntut umum yang menangani perkara tindak pidana korupsi atau eksekutor untuk putusan tindak pidana korupsi melainkan ditunjuk Jaksa Pengacara Negara (yang selanjutnya disebut JPN) untuk menangani kasus perdata yang diajukan oleh Pelawan sebagai Terlawan. Studi terdahulu juga menegaskan bahwa terkait pengembalian keuangan negara dapat dilakukan melalui dua instrument hukum, yaitu instrumen pidana yang dilakukan oleh Penyidik dan instrumen perdata dilakukan oleh Jaksa Pengacara Negara Instrumen pidana lebih lazim dilakukan karena proses hukumnya lebih sederhana dan mudah. ${ }^{11}$

Peran jaksa bisa sebagai Jaksa Pengacara Negara juga di lain sisi sebagai pejabat gungsional yang memiliki wewenang sebagai penuntut umum. Berkaitan dengan peran jaksa sebagai penuntut umum diatur dalam Pasal 1 angka 1 Undang-undang Nomor 16 Tahun 2004 tentang Kejaksaan. Jaksa bertindak sebagai penuntut umum dan pelaksanaan putusan pengadilan yang telah memperoleh kekuatan hukum tetap serta wewenang lain berdasarkan undang-undang. Jaksa sebagai penuntut umum juga diatur dalam KUHAP melalui Pasal 1 butir 6 huruf a dan b Jo. Pasal 13 bahwa penuntut umum sudah pasti seorang jaksa sedangkan jaksa belum tentu seorang penuntut umum.

Kejaksaan sebagai salah satu lembaga penegak hukum dituntut untuk lebih berperan dalam menegakkan supremasi hukum, perlindungan kepentingan umum, penegakan hak asasi manusia, serta pemberantasan korupsi, kolusi, dan nepotisme (KKN). Dibidang pidana, Kejaksaan mempunyai tugas dan wewenang: melakukan penuntutan, melaksanakan penetapan hakim, melakukan pengawasan, melakukan penyidikan, melengkapi berkas perkara sebagaimana diatur dalam Pasal 30 Undangundang Kejaksaan.

Peran dan tugas jaksa lainnya diantaranya: melakukan pengawasan atas pelaksanaan putusan lepas bersyarat serta sebagai Jaksa Pengacara Negara manakala negara menjadi pihak dalam gugatan perdata. Sebagai pengacara negara, peran jaksa ditujukan untuk memulihkan kerugian negara dan menyelamatkan kekayaan negara, hanya negara yang dapat dibela oleh Jaksa Pengacara Negara. ${ }^{12}$ Di bidang perdata dan tata usaha negara, kejaksaan dengan kuasa khusus dapat bertindak baik di dalam maupun di luar pengadilan untuk dan atas nama negara atau pemerintah. Kewenangan jaksa secara lebih khusus dalam bidang perdata juga berkaitan dengan

10 Lihat Pengertian Jaksa Pada Pasal 1 angka 6 huruf a KUHAP, "Jaksa adalah Pejabat yang diberi wewenang oleh undang-undang ini untuk bertindak sebagai Penuntut Umum serta melaksanakan putusan Pengadilan yang telah memperoleh kekuatan hukum tetap".

11 Lukas, A. P. (2010). Efektivitas Pidana Pembayaran Uang Pengganti Dalam Tindak Pidana Korupsi (Studi Putusan Tindak Pidana Korupsi di Pengadilan Negeri Purwokerto). Jurnal Dinamika Hukum. 10(2). h. 83.

12 Sandjaya, R. W. (2015). Peran Jaksa Dalam Perkara Perdata Berdasarkan Pasal 30 Ayat (2) Undang-undang No 16 Tahun 2004 Tentang Kejaksaan Republik Indonesia. Kumpulan Jurnal Mahasiswa Fakultas Hukum. (1). h. 15-17. 
mewakili negara dalam bidang kepailitan. Kejaksaan berwenang untuk memohon pailit sebagaimana diatur dalam Undang-undang Kepailitan untuk kepentingan umum, yaitu kepentingan bangsa dan negara. ${ }^{13}$ Peranan kejaksaan pada bidang perdata dalam sejarahnya bukanlah merupakan hal yang beru karena sebelumnya berdasarkan Staatsblad Nomor 522 Tahun 1922, kejaksaan diberi tugas dan fungsi di bidang hukum Perdata, juga fungsi tersebut juga diatur dalam Burgerlijke Wetboek, khususnya Pasal 463 Kitab Undang-undang Hukum Perdata berkaitan dengan wewenang keperdataan dari kejaksaan, seperti wewenang kejaksaan mengajukan permohonan kepada pengadilan terkait pengurusan harta orang yang meninggalkan tempat tinggalnya tanpa memberitahukan tempat tinggal baru dan tanpa kabar berita. ${ }^{14}$ Sebagai pengacara negara, peran dan fungsi jaksa berkaitan dengan pengembalian keuangan dan atau aset negara, jaksa bertindak baik sebagai penggugat maupun sebagai tergugat. Peran tersebut merupakan bentuk dari wewenang lain yang diberikan kepada jaksa berdasarkan undang-undang.

Tugas dan wewenang kejaksaan yang bertindak sebagai Jaksa Pengacara Negara, diperjelas di dalam Pasal 30 Ayat (2) Undang-undang Nomor 16 Tahun 2004 tentang Undang-undang Kejaksaan RI. Profesi Jaksa memiliki aturan hukum berdasarkan Undang-undang Kejaksaan RI. Pertanyaan yang muncul ketika jaksa diberikan kuasa untuk beracara di dalam perkara perdata, legal atau tidak untuk mewakili sebagian besar kepentingan masyarakat dan negara, berdasarkan undang-undang kejaksaan ada 2 pasal yang mengatur tentang kewenangan jaksa dalam perkara perdata, yaitu:

1. Pasal 30 ayat (2), “di bidang Perdata dan Tata Usaha Negara Kejaksaan dengan kuasa khusus dapat bertindak di dalam maupun diluar pengadilan untuk dan atas nama negara atau pemerintah".

2. Pasal 34, "Kejaksaan dapat memberikan pertimbangan dalam bidang hukum kepada pemerintah lainnya". ${ }^{15}$

Perpres RI Nomor 38 Tahun 2010 tentang Organisasi dan Tata Kerja Kejaksaan Republik Indonesia Jo Perpres Nomor 29 Tahun 2016 tentang Perubahan Perpres Nomor 38 Tahun 2010 tentang Organisasi dan Tata Kerja Kejaksaan Republik Indonesia, diatur dalam:

1. Pasal 24 ayat (1), “Jaksa Agung Muda Perdata dan Tata Usaha Negara mempunyai tugas dan wewenang melaksanakan tugas dan kewenangan Kejaksaan di bidang perdata dan tata usaha negara";

2. Pasal 24 ayat (2), "lingkup bidang perdata dan tata usaha negara sebagaimana ayat (1) meliputi penegakan hukum, bantuan hukum, pertimbangan hukum, dan tindakan hukum lain kepada negara atau pemerintah meliputi lembaga/badan negara, lembaga/instansi pemerintah pusat dan daerah, badan usaha milik

${ }^{13}$ Arjaya, B. W. (2014). Wewenang Kejaksaan Sebagai Pemohon Pailit Untuk Kepentingan Negara Terhadap Utang Pajak Subyek Hukum Dari Negara Anggota Asean Non-Indonesia Pasca Berlakunya Aec. Jurnal Rechts Vinding: Media Pembinaan Hukum Nasional. 3(2). h.199.

14 Rusdianto, R. (2015). Fungsi Kejaksaan Sebagai Pengacara Negara Dalam Perspektif Penegakan Hukum Di Indonesia. Jurnal Cakrawala Hukum. 6(1). h. 100.

15 Effendy, M. (2005). Kejaksaan Republik Indonesia, Posisi dan Fungsinya dari Perspektif Hukum. PT. Gramedia Pustaka Utama. Jakarta. h. 136. 
negara/daerah di bidang perdata dan tata usaha negara untuk menyelamatkan, memulihkan kekayaan/keuangan negara, menegakkan kewibawaan pemerintah dan negara serta memberikan pelayanan hukum kepada masyarakat". ${ }^{16}$

Berdasarkan peraturan perundang-undangan dan uraian kasus posisi sebagaimana tersebut diatas, dapat dikemukakan bahwa peran Jaksa dalam gugatan pihak ketiga terhadap barang sitaan dalam perkara tindak pidana korupsi adalah sebagai pihak Terlawan yang diwakili oleh Jaksa Pengacara Negara untuk melaksanakan tugas dan wewenangnya dalam penegakan hukum bidang perdata sebagaimana dimaksud dalam Pasal 294 huruf b Peraturan Jaksa Agung RI Nomor 006/A/JA/03/2014 tentang Perubahan Atas Peraturan Jaksa Agung RI Nomor: 009/A/JA/01/2011 tentang Organisasi dan Tata Kerja Kejaksaan Republik Indonesia yang bertindak atas surat kuasa khusus.

\section{Kesimpulan}

Upaya Hukum yang dapat dilakukan oleh pihak ketiga yang beritikad baik terhadap benda sitaan dalam perkara tindak pidana korupsi harus sesuai dengan pasal 19 Undang-undang Nomor 31 Tahun 1999 tentang Pemberantasan Tindak Pidana Korupsi. Peran jaksa dalam perkara perdata bukan sebagai penuntut umum atau eksekutor, akan tetapi dalam perkara gugatan yang dilakukan oleh Pelawan terhadap Kejaksaan RI adalah sebagai Jaksa Pengacara Negara berdasarkan Pasal 30 Ayat (2) Undang-Undang Nomor 16 Tahun 2004 tentang Kejaksaan Republik Indonesia. Sehingga perlu dilakukan penyempurnaan mengenai pengertian dari pihak ketiga yang beritikad baik, sebagaimana diatur dalam Pasal 19 Undang-undang nomor 31 Tahun 1999 tentang Pemberantasan Tindak Pidana Korupsi, agar tidak terjadi penafsiran secara bebas terhadap pasal tersebut.

\section{Daftar Pustaka}

$\underline{\text { Buku }}$

Afiah, R. N. (1989). Barang Bukti Dalam Proses Pidana, Jakarta: Sinar Grafika.

Effendy, M. (2005). Kejaksaan Republik Indonesia, Posisi dan Fungsinya dari Perspektif Hukum. PT. Gramedia Pustaka Utama. Jakarta.

Harahap, M. Yahya. (2016). Pembahasan dan Penerapan KUHAP: Pemeriksaan Sidang Pengadilan, Banding, Kasasi, dan Peninjauan Kembali. Cetakan Kelima Belas. Jakarta: Sinar Grafika.

Wahyudi, B.S. (2017). Indonesia Mencegah: Upaya Pencegahan Korupsi Oleh Kejaksaan Bidang Perdata dan TUN. Bhuana Ilmu Populer. Jakarta.

Yusuf, Y., Nurholish, R. (2010). Perlindungan Hukum Pihak Ketiga Yang Beritikad Baik Atas Barang Bukti Yang Dirampas Untuk Negara Dalam Perkara Tindak Pidana Korupsi. Bandung: Fakultas Hukum Universitas Padjadjaran.

16 Wahyudi, B. S. (2017). Indonesia Mencegah: Upaya Pencegahan Korupsi Oleh Kejaksaan Bidang Perdata dan TUN. Bhuana Ilmu Populer. Jakarta. h. 249-250. 


\section{Jurnal}

Aditya, E. (2018). Penerapan Kebijakan Diskresi Dalam Kaitannya Dengan Tindak Pidana Korupsi. Jurnal Magister Hukum Udayana (Udayana Master Law Journal), 6(3), 404-416. https:// doi.org/10.24843/JMHU.2017.v06.i03.p10

Arjaya, B. W. (2014). Wewenang Kejaksaan Sebagai Pemohon Pailit Untuk Kepentingan Negara Terhadap Utang Pajak Subyek Hukum Dari Negara Anggota Asean Non-Indonesia Pasca Berlakunya Aec. Jurnal Rechts Vinding: Media Pembinaan Hukum Nasional. 3(2). 197-214.

Dewi, K. K. S. (2014). Efektifitas Penerapan Ancaman Sanksi Pidana Tambahan Guna Pengembalian Kerugian Keuangan Negara dalam Tindak Pidana Korupsi (Studi Kasus di Pengadilan Negeri Denpasar). Jurnal Magister Hukum Udayana (Udayana Master Law Journal). 3(3). 357-370. https://doi.org/10.24843/JMHU.2014.v03.103.p01

Lukas, A. P. (2010). Efektivitas Pidana Pembayaran Uang Pengganti Dalam Tindak Pidana Korupsi (Studi Putusan Tindak Pidana Korupsi di Pengadilan Negeri Purwokerto). Jurnal Dinamika Hukum. 10(2). 81-92. http://dx.doi.org/10.20884/1.jdh.2010.10.2.142

Prasetyo, R. T., Ma'ruf, U., \& Mashdurohatun, A. (2017). Tindak Pidana Korporasi Dalam Perspektif Kebijakan Formulasi Hukum Pidana. Jurnal Hukum Khaira Ummah. 12(4). 727-741.

Rusdianto, R. (2015). Fungsi Kejaksaan Sebagai Pengacara Negara Dalam Perspektif Penegakan Hukum Di Indonesia. Jurnal Cakrawala Hukum. 6(1). 99-108.

Sandjaya, R. W. (2015). Peran Jaksa Dalam Perkara Perdata Berdasarkan Pasal 30 Ayat (2) Undang-undang No 16 Tahun 2004 Tentang Kejaksaan Republik Indonesia. Kumpulan Jurnal Mahasiswa Fakultas Hukum. (1). 1-19.

Sinaryati, N. W. (2015). Fungsi Jaksa dalam Menuntut Terdakwa Korupsi untuk Pengembalian Kerugian Keuangan Negara Perspektif Sistem Peradilan Pidana Indonesia. Jurnal Magister Hukum Udayana (Udayana Master Law Journal). 4(1). 162-178. https://doi.org/10.24843/JMHU.2015.v04.i01.p13

Sinulingga, E. E. (2017). Pengembalian Aset Hasil Tindak Pidana Korupsi Melalui Mekanisme Gugatan Perdata. Lex Administratum. 5(4). 117-127.

\section{Peraturan Perundang-undangan}

Undang-Undang Nomor 1 Tahun 1946 tentang Peraturan Hukum Pidana untuk Seluruh Wilayah Republik Indonesia.

Undang-undang Nomor 18 Tahun 1981 tentang Hukum Acara Pidana.

Undang-undang Republik Indonesia Nomor 16 Tahun 2004 tentang Kejaksaan Republik Indonesia (Lembaran Negara Republik Indonesia Tahun 2004 Nomor 67, Tambahan Lembaran Negara Republik Indonesia Nomor 4401). 
Undang-undang Republik Indonesia Nomor 20 Tahun 2001 Tentang Perubahan Atas Undang-Undang Nomor 31 Tahun 1999 Tentang Pemberantasan Tindak Pidana Korupsi (Lembaran Negara Republik Indonesia Tahun 1999 Nomor 140, Tambahan Lembaran Negara Republik Indonesia Nomor 3874).

Perpres RI Nomor 38 Tahun 2010 tentang Organisasi dan Tata Kerja Kejaksaan Republik Indonesia Jo Perpres Nomor 29 Tahun 2016 tentang Perubahan Perpres Nomor 38 Tahun 2010 tentang Organisasi dan Tata Kerja Kejaksaan Republik Indonesia.

Peraturan Jaksa Agung Republik Indonesia Nomor 006/A/JA/03/2014 tentang Perubahan Atas Peraturan Jaksa Agung Republik Indonesia Nomor: 009/A/JA/01/2011 tentang Organisasi dan Tata Kerja Kejaksaan Republik Indonesia.

Keputusan Jaksa Agung Republik Indonesia Nomor: KEP-518/A/J.A/11/2011 Tentang Perubahan Keputusan Jaksa Agung Republik Indonesia Nomor: KEP132/JA/11/1994 tentang Administrasi Perkara Tindak Pidana 